\title{
The Matthean community's state of coexistence between Jews and Gentiles
}

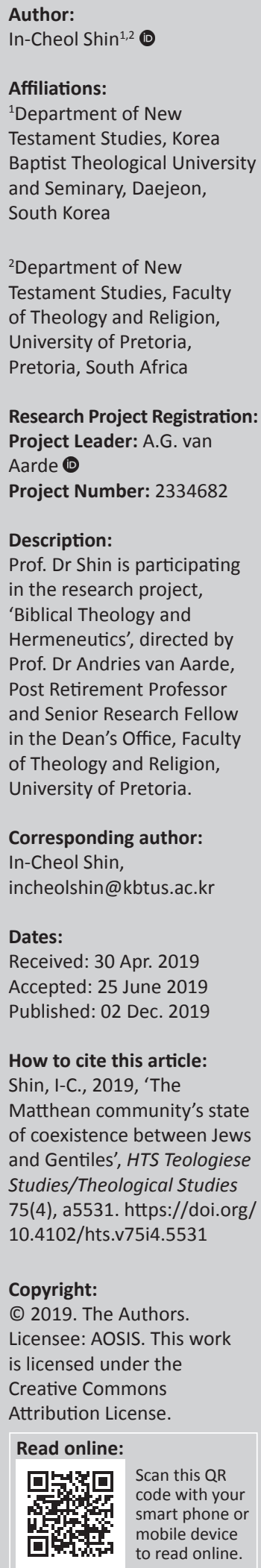

The past century has seen various studies on the nature of Matthew's community, and conclusions are still being debated. The study on which this article is based acknowledges the past studies, but further proposes that the nature of the Matthean community was one of coexistence. The Matthean community implied in the book of Matthew coexisted in three ways. Firstly, Jews and Gentiles coexisted within the community: the Jewish-Christian-centred community had started to accept Gentiles and became a community where Gentiles and Jews lived together. Secondly, the community was in a state where both the Jewish law and the teachings of Jesus were followed. Finally, the community tended to set both Jews and Gentiles as targets for the mission. This means that there was missionary coexistence within the community. These three main reasons are the basis for the claim that the Matthean community maintained the nature of coexistence.

Keywords: coexistence; Matthean community; Jews; Gentiles; mixed state.

\section{Introduction}

One of the most interesting challenges for scholars studying Matthew's Gospel is to comprehend the nature of the Matthean community, which Matthean scholars have debated inconclusively for some time (Shin 2004:2). There have been various suggestions regarding the state of the Matthean community and its character: for instance, Saldarini's (1994:1) view is that Matthew's group was a 'Christian-Jewish' form of community. Stanton (1992:93-98) claims that the Matthean community was a 'sectarian' one of the Jewish parent body. The Matthean community had a somewhat different religious perspective on Judaism, but was still deeply connected to its Jewish background. Gundry (1994:5-10) believes that the Matthean community was in a 'mixed state', consisting of true and false disciples, which engendered conflict owing to the mixed state. This view is also connected with the Matthean community's state of conflict between Jewish Christians and Gentile Christians (Saldarini 1991:38-61). Elliott's (2002:73-83; see Beed \& Beed 2015:587-607) view is that the egalitarian aspects of Jesus' disciples' communities were influenced by the teachings of Jesus. Jesus' teachings linked the egalitarian aspects with those of his disciples' community. The Gospel of Matthew clearly shows that there was equality among the disciples. Jesus taught his disciples not to sit in the seat of Moses (Mt 23:1-2). Jesus also told his disciples about the family of the Kingdom of God (Mt 10:34-36). These verses seem to support both egalitarianism and the idea of rejecting the biological family system.

This issue has led to the claim that the Matthean community managed to maintain a state of equality. Shin (2004) believes that the Gospel of Matthew demonstrates the inclusivity of the community. It can therefore be inferred that Jesus' ministry includes people from all social levels, even those who are regarded as 'lower class' people and Gentiles.

However, this argument remains a contentious issue for Matthean scholars because the nature of the Matthean community has not yet been confirmed. It is therefore necessary to reconsider what the nature of the Matthean community was. I suggest that it was one of coexistence. Although this suggestion does not deny the earlier studies of the nature of the community, it attempts to explore the new view that the community of Matthew was in a state of coexistence. Moreover, it comprised members of differing persuasions, as mentioned earlier. Therefore, my claim to a state of coexistence is based on the various theories about the Matthean community.

Two streams of research formed the foundation of my study on the state of coexistence existing in the Matthean community. This article first looks into the social situation of the Matthean community,

Note: HTS 75th Anniversary Maake Masango Dedication. 
to determine the kind of environment of its members. I examine the kinds of situations that caused conflict and also explore why the Matthean community was in an inevitable state of coexistence. I attend particularly to the conflict within the Matthean community. Secondly, I attempt to understand why the Matthean community was in a state of coexistence. This attempt will be divided into three aspects: (1) The Matthean community was in the process of accepting the teachings (logia) of Jesus as the core value of their community without being completely out of compliance with the law. (2) The members of the Matthean community still came together towards a state of coexistence. This study proves how the Jewish-centred Matthean community ended up in a state of coexistence despite the conflict with the Gentiles. (3) The Matthean community was also in a state of conflict regarding the target of the mission. Some claimed that only Jews should be the target of mission, while others claimed that both Jews and Gentiles should be targeted. In this article, I show how these two sides settled matters and came together into a state of coexistence. These three claims of the second stream of research prove that the Matthean community entered a state of coexistence by overcoming conflict.

\section{The social setting behind the state of coexistence}

The Gospel of Matthew was written in the last part of the first century (CE 80-90) by Christian communities (Smith 1992:229). The community found itself in a complex situation: no clear Christian identity had yet been established. After the Jewish war, there was conflict between members who still followed the dominant Judaism and those who were ready to follow Christianity, but were not yet equipped with a Christian identity.

Various scholars have been interested in the social situation of the community of Matthew.

Kingsbury (1991:264-265), one of the most distinguished scholars in the field, covers the whole field of the social situation of the Matthean community in detail (Kampen 1994:338-339). I next discuss the fields that play an important role in understanding the state of the community of Matthew.

The Matthean community was located in an urban environment of Antioch in Syria (Meier 1976:8-9; White 1991:217-221).

While the lifestyle and function of the city in the 1st century of the Mediterranean world is not known, the following could possibly be inferred: in general, the city was in a state of urban disorder, social dislocation, misery and cultural chaos (Stark 1991:190). There were many reasons why ancient Antioch society fell into chaos, but the biggest problem was that it was a multi-ethnic city. In the 1st century, Greco-Roman cities in the Mediterranean demanded the continued and substantial introduction of newcomers to maintain their populations (Stark 1991:196), with the purpose of demonstrating the power of the city. The diverse people who came into the city brought their culture and traditional customs.
In the case of the city of Antioch, the population of the city increased because of historical changes. Stark (1991:196) points out that ' $[t]$ he first ethnic origins that settled in the city of Antioch were the retired soldiers of the Seleucus' Macedonian army, Cretans, Cypriotes, Argives, and Herakleidae'. These ethnic groups lived near the city of Antioch until they moved into Antioch and played a role in making the city a multi-ethnic society. The Jews probably came to Antioch from nearby Palestine. As the Roman Empire ruled Syria, the number of Jews immigrating to Antioch increased rapidly (Meeks \& Wilken 1978).

If one looks at the ethnic aspect, it is clear that the early members of the Matthean community were predominantly Jewish Christians (see Van Veen 2018:66). However, over time the Matthean community began to accept Gentile members into the community. The Jewish and Gentile members lived together within a hierarchical structure (Beed \& Beed 2015:598-602; Gundry 1994:5-10). However, it is still unsure whether the Gentiles outnumbered the Jewish members. The social setting of the Matthean community was also problematic, on both the inside and the outside. According to Saldarini (1991:38-61), the Gospel of Matthew reflects the conflict between the community and the Jews. This echoes the statement by Barth (1963:111): '[ $h]$ is community seeks to keep fellowship with the Jewish nation, but the situation is tense; the church is directly persecuted'. Overman (1996) mentions that the Matthean community was in a crisis too.

Therefore, many scholars contend that the Matthean community was facing a crisis of conflict with Judaism because of the surrounding environment, social circumstances and internal conflict.

Stanton's (1985:1914-1921) view that the Matthean community separated from Judaism over opposite perspectives regarding Judaism fails to deliver a conclusive explanation merely from this perspective. Some scholars claim that some community members were in conflict with other Jews, but still remained within Judaism (cf. Sim 2001:270). This view contrasts with other authors' contention that the conflict led the Matthean community to cut all ties with its parent religion (Schweizer 1975:425; Stanton 1992:96-97; Stendahl 1968:30-35). This issue has not been resolved among modern Matthean scholars. However, one important fact is evident here: scholars are unsure of the exact relationship between the community of Matthew and Judaism. Therefore, the religious ideas that were common to the two groups need to be examined.

The scholars who analysed the Gospel of Matthew from a sociological standpoint came to the conclusion that the Matthean community was a Jewish sect (Sim 2001:272). While they agree that the Matthean community was a sect of Judaism, they presented different perspectives. Overman's (1990:8) view was that the Matthean community was not at all different from any other Jewish sect that existed at the time of the Qumran community. Saldarini (1991:48-49) claimed that the community of Matthew betrayed and deviated from the 
Jewish way of viewing and interpreting the Bible. The Matthean community's use of offensive language when referring to Judaism shows that it was on the road to disconnecting from Judaism and developing into a new type of Christianity. However, despite this situation, the Matthean community did not cut all ties with Judaism but still shared ideological religious traditions. The Matthean community, which had not been able to separate from Judaism and had yet to establish a Christian identity, coexisted.

\section{Matthean community's state of coexistence \\ Mixed state of Jews and Gentiles}

The text of the Gospel of Matthew contains many references to the Matthean community's being composed of good and bad members (see Carter 2004:260). The following are some texts that represent the mixed state:

The kingdom of heaven is like a net with all kinds of fish. When it was full, the fishermen collected the good fish in baskets, but threw the bad away. (Mt 13:47-50)

When all the nations are gathered before the Son of Man, he will separate the people one from another as a shepherd separates the sheep from the goats. He will put the sheep on his right and the goats on his left. (Mt 25: 31-46)

This issue has already been discussed by many scholars (Gundry 1994:5-10; see Luomanen 1998:469) and has elicited various perspectives on the mixed state of the Matthean community. Some scholars claim that the Gospel of Matthew does not divide people as elected or not elected, but believe that the good and the bad will be discerned at the last judgement (Bornkamm 1963:19). Gundry (1994:5-10) claims that the Matthean community is mixed with false and true disciples. These are all plausible and acceptable arguments, showing the mixture of good and bad in the ecclesiological situation of the community and the nature of Matthew's congregation (Luomanen 1998:470). However, because one cannot confirm who was good or bad in the Matthean community, this article covers only the situations of the good and the bad in the Matthean community. I will refer to some relevant texts from the Gospel of Matthew.

The parable of weeds and its explanation clearly indicates that the Matthean community was in mixed state (Mt 13: 24-30, 36-43). The study of this text begins with the question of whether the parable of weeds depicts the Christian community. Most Matthean scholars argued that the parable is not connected directly with the Matthean Christian community (Davies \& Allison 2006b: 428; McIver 1995:646), but should be seen as a portrayal of the state of the community. The core feature of this parable is the content about the bad within the Matthean community. This parable is about the kingdom of God and reflects the state of the Matthean community and how the words of Jesus Christ were accepted in this community (Luz 2001:254).

Of importance is Matthew 13:29-30: Jesus does not pull out the darnel, but waits for the harvest. In this parable, the word 'darnel' refers to the 'bad' character. This once again means that the Matthean community is not a holy organisation, but a mixed body of the good and the bad. Here one should pay attention to the fact that the unrighteous will not be separated from the righteous until the day of judgement.

Normally, farmers need to pull up the darnel to protect the wheat (Mt 13:30), but here the farmer orders that the tares be left until the harvest.

On analysing the state of the community of Matthew through this parable, it can be seen that the bad refers to some Jewish members of the Matthean community who did not follow Jesus fully (Luz 2001:254).

The Gospel cautions that one should be careful not to segregate prematurely those who are hostile towards Jesus, or 'bad', from the community. It is important not to pull up the darnel until the future judgement of God. This is a significant reason why the community allowed the coexistence of the good and bad. The Gospel of Matthew has more stories about mixed states such as the one suggested in this parable. The most representative text among them is that of the wedding feast (Mt 22:1-14). The fact that the text warns us against false prophets implies that there were false (bad) prophets living within the community. This is evidence that in the community of Matthew both good and bad people coexisted.

\section{Coexistence of Jesus' teachings and the law}

It has already been explained that the Matthean community was in a state of coexistence. Next, the concrete situation of the Matthean community's state of coexistence is examined. The best manifestation of the coexistence of the Matthean community can be found in the attitude of the Matthean community towards the law. In general, the community was recognised as a Jewish sect who observed the law (Overman 1990:78-90; Saldarini 1994:124-64; Sim 1998:123-39). It is undeniable that the Matthean community observed the Jewish law until the end of the day (Mt 5:17-19), which shows that the community of Matthew did not abandon the law even after they had accepted Jesus' teaching (Ulrich 2007:76). However, after the destruction of the temple in Jerusalem resulted in the abolition of the law, the Matthean community started to reject the law as rabbinical Judaism (Thiesen 2012:544). I now examine in detail how the Torah played a part in making the Matthean community one of coexistence.

Jesus' relatively ambiguous attitude towards the law in the Gospel of Matthew is examined next. Jesus' purpose in coming to the earth was not to abolish the law but to complement it (Mt 5:17) (see Evans 2011:106; Van Veen 2018:68). The Matthean Jesus did not only distinguish between the important and less important issues of the law, but he also interpreted some laws differently from the Pharisees. Matthean Jesus and the rabbinic Judaism had different purposes for interpreting the law. The Matthean community, following Jesus, showed a tendency to regard mercy as more important than keeping the law as prescribed 
(Mt 12:7). Jesus' teachings are not merely about ethical mercy, but the opposite of the rabbinical teaching of the Sabbath law (Luz 2001:182; see Van Veen 2018:67). Matthean Jesus showed a greater tendency to think more of the teachings of peace, love, faith and faithfulness than to obey the provisions of the law, such as tithing and following Sabbath regulations (Mt 23:23). Of course, Jesus' teachings did not mean that one was to abolish the tithe to be given to God; rather, Jesus emphasised that mercy, justice and faith were more important than the law (Luz 2005:124).

These verses in the Gospel of Matthew illustrate that when compared, there is a significant difference between Jesus' and the rabbis' interpretation of the law. Jesus' interpretation suggests that when comparing the laws of Matthew and Mark, one can find significant differences between the two Gospels. Basically, there are stories in the Gospel of Mark about conflicts that arose because of Jesus' interpretation. The Gospel of Mark shows that Jesus often tended to break or reject the law, a picture that is quite different from the Matthean Jesus (Sim 2001:273-274). However, even though the Gospel of Mark seems to turn away from the law, it still has a tendency to adhere to the law. On the contrary, Matthew's community still observed the law. Jesus, the Scribes and the Pharisees were always in conflict regarding the correct interpretation of the law. One of the biggest causes of the conflict between the Matthean community and rabbinical Judaism is the difference between how each group interprets the core meaning of the law (Thiesen 2012: 553-554). Conflicts like these did not only occur between the community and Judaism but also occur within the community where members were confused about observing the law or the teachings of Jesus.

The law was the standard used to distinguish God's people and Gentiles. Jews had to adhere to the demands of the law because they had a covenant with God. If a Gentile converted to Judaism, he or she had to abide by the laws observed by the people of Israel Hare (2000:271). However, it has already been confirmed that the community of Matthew did not observe the law as much as the rabbinic Judaism required. Sim (2001:274) argues that the Matthean community viewed themselves as 'Christian Jews' by showing respect for the law and adhering to it. They also claimed that their religious tradition was Christian Judaism. Thus, Sim claims that the Matthean community still believed in Jesus while maintaining the Jewish faith. I agree with some of Sim's views, but I cannot agree that the Matthean community maintained the Jewish faith. Although the Matthean community was a Jewish sect, it was already losing the basic characteristics of the Jewish faith.

The Matthean community was undergoing conflict as it was separating from the Jewish parent body.

However, the Matthean community did not merely experience conflict with Judaism, but it applied the teachings of Jesus and tried to coexist with the rest of the community by merging the law and the teachings of Jesus.
I will now examine how the Matthean community accepted Jesus' teachings. The Gospel of Matthew abounds with the teachings of Jesus. The community of Matthew treated the word of Jesus as superior or at least equal to the Torah of Moses (see Mt 24:35: 'The heaven and earth will disappear, but my words will remain forever'). It has already been confirmed that the law is eternal (Mt 5:18). The disappearance of heaven and earth can be seen as a parable of eternity. Matthew's claim that Jesus' teachings will not go away but will remain forever is similar to the expression frequently used by the rabbis of Judaism, who held that the Torah would not be lost but would last forever (Bar 4:1; Wis 18:4; 2 Eadr 9:37). The rabbis granted this authority to the Torah only (Luz 2005:208), but the fact that the first evangelist gave Jesus' teachings the same authority as the Torah shows clearly how Jesus' teachings were valuable to the Matthean community.

Matthew regarded Jesus' teaching as the same as the Torah, which means that the Matthean community considered Jesus' teachings to have the same authority as the Torah.

Therefore, the community of Matthew can be seen to have kept a life of faith in keeping with the teachings of both the Torah and Jesus. While still observing the teachings of the Torah, the community of Matthew also accepted the teachings of Jesus and set them as the standard of their community life. This means that the Matthean community was in a situation where the teachings of the Torah and Jesus coexisted.

\section{Coexistence regarding the mission for Jews and Gentiles}

In his analysis, Van Aarde (2005:416-417) writes about Jesus' view on mission in the Gospel of Matthew. The terms 'true Israel' and 'new Israel' suggest that the community of Matthew was considering both Jews and Gentiles as targets for its mission (see Balabanski 2008:161). To be more precise, the first evangelist uses the phrase 'new people', which represents both Jews and Gentiles. Stanton (1992:11) claims that the community of Matthew was active in both the Gentile mission and the Jews' mission, pursuing the road to universal mission. From a slightly different point of view, it is argued that the Matthean community was intended to create an ecumenical community of Jews and Gentile Christians allied (Senior 2001:18).

However, Saldarini (1994) contends that the Matthean community still retained the fragile Jewish identity as a group. I agree with the view of Saldarini and propose a hypothesis that the Matthean community, which Saldarini claimed was a small group, was still pursuing a new identity while being a part of Judaism and agreeing with the view that they were working together on missions towards the Jews and Gentiles (Repschinski 2006:265). Some of the Jewish Christians in the Matthean community opposed the Gentile mission and were in conflict with the members who were positive towards the Gentile mission. These members, with their own different perspectives on Gentile missions, would gradually blend, establishing the identity of their community. Eventually, the 
community of Matthew changed into a community that was oriented towards Jewish and Gentile missions.

I now look at this state of the community through an analysis of the text of the Gospel of Matthew. The Matthean community's mission for the Gentiles proceeded through these stages, and this situation formed the state of mission coexistence. Jesus is described as the Saviour of Israel in the Gospel of Matthew.

Matthew's narrative structure describes Jesus' ministry very well. If one were to divide the Gospel of Matthew, one would divide it into two parts, namely the period of Historical Jesus and the period of the Matthean community. The narrative clearly shows that the target of the Historical Jesus' mission was all of Israel (Van Aarde 2007:430). The reason behind this claim is that the Gospel of Matthew states that Jesus will save the Israelites just like Moses and Joshua who were sent by God to save the Israelites. In the Gospel of Matthew, Jesus is portrayed as a Davidic Messiah, and the centurion of Rome recognised Jesus as the king of Israel, not the King of Rome, when he believed in Jesus as Saviour (Mt 27:54) (Carter 2001:76; Van Aarde 2007:425).

Matthew clearly suggests that God sent Jesus to earth as a mission to save Israel. The people of Israel were the chosen people of God as the descendants of the Abrahamic promises. However, Matthew believes that all Jews are not automatically saved on the basis of their ethnic identity (Runesson 2011:140). Jesus said to the religious leaders, '... and do not think you can say to yourselves, "we have Abraham as our father." I tell you that out of these stones God can raise up children for Abraham' (Mt 3:9). This verse shows us that not only Jews, but also Gentiles are considered the children of God and Matthew saw God's plan for salvation including other nations. Hence, Jesus came down to earth according to God's will with the purpose of redeeming both Jews and Gentiles (see Carter 2004:260). The narrative of the Gospel of Matthew says that the God of Israel sent Jesus to save Israel in the period of pre-Easter narration and the Gentile mission became active in the period of postEaster narration by the community of his disciples (Van Aarde 2007:431; see Repschinski 2006:249). As indicated above, the teachings of historical Jesus were reflected through the community of his disciples. Thus, the Gentile mission of the Matthean community is a sequel to the Jewish mission of historical Jesus (cf. Balabanski 2008:164-165; Sim 2014:518).

This analysis shows that the original target of mission of Matthew's community was Israel. I will look at the occasions and circumstances in which the Matthean community preached the Gospel to the Gentiles. It seems that the Matthean Jewish-Christian community began the Gentile mission as it started to separate from the parent body of Judaism. The fact that the community of Matthew began to embrace Gentiles as members of its communities means that they had shifted from Jewish mission to Gentile mission. The controversy over the claim that the community of Matthew turned towards the Gentile mission begins with a positive assessment about the Gentiles mentioned in Matthew
(Clark 1947:165-172). Many positive references can be found relating to Gentiles in the Gospel of Matthew; furthermore, Jesus proclaimed the kingdom of God to Gentiles in the Gentile world (Mt 1:1; 4:15-16; 8:5-13; 12:18-19; 15:21-39).

I now turn to the reason that the community of Matthew began to do Gentile missions. One of the motivations of the Gentile mission was to delay Parousia. After the resurrection of Jesus, the disciples' communities were no longer able to preach the Gospel to the Jews, and they began to preach the Gospel to the Gentiles (Brown 1980:194). In the aftermath of the Jewish War, the Matthean community moved to the Gentile neighbourhood of Antioch in Syria and faced a situation where they had to accept Gentiles into their communities (Brown 1983:215; see Balabanski 2008:163).

An analysis of the situation of the Matthean community and the text provides further details on why the Matthean community switched its target from Jews to Gentiles. The community of Matthew moved to the Gentile world and actually became a part of the lives of the Gentiles rather than the Jews. The relations with Judaism had turned hostile, and this situation forced the community to begin the Gentile mission (cf. Carter 2004:280). The Jews made and used Birkath Ha Minim prayers to curse pagans as well as the Christian community (Joubert 1993:361). There was no doubt that Orthodox Judaism was hostile towards the Jewish Christianity (Brown 1983:215). The launching of the Gentile mission alone was a significant reason for the persecution of the Matthean community by Orthodox Judaism. The Gospel of Matthew was probably written at the time when the community of Matthew began the Gentile mission (CE 85).

The first evangelist makes a clear statement through the words of Jesus that the Matthean community was to conduct Gentile missions (Mt 28:18-20). The fact that it had been proclaimed by Jesus, as recorded at the end of the Gospel of Matthew (Mt 28:19), indicates that the Matthean community was switching to a mission for the Gentiles (Repschinski 2006:250; Van Veen 2018:70). This switch, as well as other changes such as the termination of the circumcision ceremony, was an enormous change that was difficult for the community to absorb because the community still felt part of Judaism (Brown 1980:218). However, the initiation of the Gentile mission does not mean that the community rejected the Jewish mission (cf. Mt 12: 20-21) (Carter 2004:272). The Great Commission in the Gospel of Matthew refers to both Jews and Gentiles.

To understand the meaning of the teachings of Jesus clearly, one must understand that Jesus' Great Commandment was to make disciples of all nations - hence, the disciples were sent to 'all nations' (Mt 28:19). 'Jesus' commission to make disciples of 'all nations' does revoke the restriction of the mission to just Israel made in Matthew 10:5' (Balabanski 2008:169). However, it is debatable whether the phrase 'all nations' does in fact mean all nations or all Gentiles. Moreover, it is unclear whether it includes Israel or not (Luz 
2005:628). It is worth looking into whether the phrase 'all nations' in the Gospel of Matthew refers to a collective of nations other than Israel and to those individual Gentiles who are not Jews (Hare \& Harrington 1975:360). According to Hare and Harrington, the term 'all nations' refers to foreign nations and specifically those who competed with the nation of Israel (Hare \& Harrington 1975:360). Moreover, throughout the Hellenistic and Persian period, the term 'nation' was used to refer to mankind except the Jews, rather than to represent the national groups such as Greeks or Egyptians (Hare \& Harrington 1975:360). From this point of view, the 'nation' is not a national organisation, but a stranger who stands against the Israelites. From a sociological standpoint, in particular, it may be seen as a term referring to a particular type of people who emigrated from other countries and made up the collective people of non-Israel.

In an attempt to solve this problem, it is necessary to analyse how the term 'ethnicity' was used in the Gospel of Matthew. In the Gospel of Matthew, the word 'nation' is mentioned frequently (Mt 4:15; 6:2; 10:5, 18; 12:18; 20:19, 25; 21:43; 24 7, 9, $14 ; 25: 32 ; 29: 19)$. The meaning can be discussed under five main points.

Firstly, 'the nation' was used as to refer to the Gentiles (Mt 20:25). When the mother of Zebedee asked Jesus to sit at the right and left side of the children when the kingdom of God came, 'the ruler of the ethne and the meaning of ethne' is Gentile. Ethne as used here must be seen as referring to the ruler of Gentiles because it represents the abuse of power that oppresses and persecutes (Davies \& Allison 2006b:93; Luz 2001:544). The word ethne used in Matthew 6:32 also refers to the Gentiles. It is an act of the Gentiles to care about food, drinking and clothes to wear. This is related to the false prayer of the Gentiles in Matthew 6:9, thus representing the Gentile who fails to trust in God's providence (Davies \& Allison 2006a:658).

Ethne in Matthew 20:19 is also seen as representing the Gentiles because those who crucified and executed Jesus were Gentiles under the authority of the Roman Empire. Therefore, the three instances of ethnos undoubtedly refer to Gentiles.

Secondly, ethnos and ethnon used in Matthew 24:7, 9 may include Israel. The background of these two verses is the end of the world and the signs of the Parousia (Balabanski 2008:170174). The ethnos mentioned here refers to all nations that belonged to the Roman Empire during the post-Jewish war.

Therefore, the 'nations' referred to here can be seen to include Israel (Luz 2005:192; Olmstead 2011:117-118).

Thirdly, I look at the verses in which the meaning of 'nation' includes Israel. Matthew 24:14 states that the Gospel of the Kingdom will be preached to all nations and that the end of the world will come. The text of the Gospel of Mark also reads, '.. the gospel must be preached to all people' (Mk 13:9-10). Therefore, this passage is not merely a preaching of the Gospel only to the Diaspora Jews, but a universal mission for the post-Easter period (Davies \& Allison 2006b:343-344). 'Nation' in this verse includes Israel because the eschatological warning in the Gospel of Matthew is applicable to all nations, including Israel.

Fourthly, the statement in Matthew 25:32 that 'all the nations will be gathered before him' also shows that 'all the nations' includes Israel. This verse is quoted from Isaiah 66:18 ('I am coming to gather all nations').

For a long time, there was a controversy over who the 'nations' were in this verse (see Davies \& Allison 2006b:422). In the text, 'nations' does not mean the Matthean community members. However, the text above is from a missionary context. The Gospel of Matthew claimed that the day of the end will come only when the Gospel had been proclaimed to all nations (Mt 24:14). Therefore, the viewpoint of the mission in the Gospel of Matthew was not limited to the Gentiles who did not know Jesus Christ (Luz 2005:275). This means that the mission target of the community of Matthew was all nations, including the Israelites.

Finally, one needs to consider whether the term 'nation' used by Matthew had been influenced by the Old Testament in any way. Trilling (1964:26-28) asserts that 'all nations' included Israel in the Gospel of Matthew, on the grounds that the term 'nation' in the Gospel of Matthew is qualified by the adjective 'all' (Mt 24:9, 14; 25:32; 28:19), which means that both Gentiles and Israel are included. For example, the eschatological judgement of Matthew 25:32 reflects the eschatological concept of the Old Testament, and both the Gentiles and the Israelites are included in the universal judgement of the Old Testament (Trilling 1964:27). Of course, not all the verses that contain the judgement of the 'nation' imply the judgement of Israel and Gentiles in the Old Testament (see Jl 3; Ez 39), when Old Testament chapters describe Israel as being subject to God's judgement when the final day comes (Hare \& Harrington 1975:364). The statement that both Israelites and Gentiles will be judged by God can be found in both the ancient literature and the New Testament:

Then shall we all be changed, some into glory and some into shame; for the Lord judges Israel first for the unrighteousness which they have committed. And then so all the Gentiles. (Armenian text of Test. Benj. 10:8-9)

Furthermore, '[t]here will be Judgment on those who do trouble and the order will be Israel first and the Gentiles next' (Rm 2:9-10). Matthew 25:31-46 is a continuation of verses 24:29-31 ('all the tribes of the earth'); the 'people' mentioned in verse 32 must be understood from a universal point of view. So, the 'nation' in verse 32 indicates non-Christians. Thus, 'nation' in this verse implies both Israelites and Gentiles, who are 'non-Christians' (see Olmstead 2011:131).

To summarise, the community of Matthew continued the mission of Israel according to the order of Jesus, and thereafter, they also started the Gentile mission. The fact that 
Jesus limited the preaching of his disciples to the Israelites during his earthly ministry (Mt 10:5-7) means that the historical Jesus commanded his disciples to preach the Gospel only to the lost sheep of the house of Israel (Mt 15:24). The public ministry of the historical Jesus stands in the position of geographical and national limitation. The Gospel was preached only to Israel and only for the promised land. However, after the resurrection, this limitation was superseded by Jesus' command (28:16-20). Therefore, the Matthean community's mission extended to all nations (Meier 1975:205). The Gospel of Matthew tends to have a positive view on Gentiles and the Gentile missions. ${ }^{1}$ All the texts related to these issues show that the Matthean community was in a state of coexistence regarding the missions for Gentiles and Jews.

\section{Conclusion}

From the end of the last century to the early part of this century, the study of the nature of the relevant community was an important part of Matthean scholarship. This research argues that the Matthean community was in a state of coexistence of Jews and Gentiles. There is substantial evidence in the text of the Gospel of Matthew that this was indeed the case. As the Matthean community was located in the Gentiles' territory, it was possible for both Jews and Gentiles to become members of the community.

The Matthean community, which was in the process of separating from the parent body of Judaism, had yet to establish a Christian identity because some members of the community did not acknowledge Jesus as the Messiah. Therefore, good and bad coexisted within the community, in a state of coexistence that will continue until the day of judgement. Because the Matthean community began as a sect of Judaism, it tended to emphasise the teachings of the law. However, this community eventually began to change into a community that regarded Jesus' teachings as more important than the Law of Moses. This, of course, does not mean that the Matthean community abrogated the Mosaic Law; rather, it formed an amalgamation of the Law of Moses and the teachings of Jesus. It was also in a state of coexistence regarding the mission. The early Matthean community aimed to preach the Gospel to the Jews. However, after the resurrection of Jesus, the community of Matthew switched attention to the Gentiles as the target of mission, but this does not mean that the community of Matthew gave up on mission for the Jews. Therefore, the Matthean community preached the Gospel to both Jews and Gentiles and the mission was in a mixed state of coexistence. This study ultimately showed that the community of Matthew was in a state of coexistence of Jews and Gentiles.

1.Various indications in the Gospel of Matthew support this view. The text of the Gospel already contains numerous positive texts about Gentile missions. A Gentile woman appears in the genealogy of Jesus (Mt 1: 3,5). The Gospel of Matthew also introduces the Gentile centurion as a man of faith who confesses, 'Surely he was the Son of God' (Mt 8:5-13;27:54). Jesus also healed the demon-possessed daughter of a Canaanite woman who was a Gentile (Mt 21-28). Therefore, the loosening of restrictions that took place after the resurrection was already being suggested. As a restrictions that took place after the resurrection was already being suggested. As a
result, the community of Matthew is seen to have been in a state of coexistence, in which both Israel and the Gentiles were objects of mission.

\section{Acknowledgements}

The author would like to acknowledge and thank Prof. A.G. van Aarde for the support provided.

\section{Competing interests}

The author has declared that no competing interests exist.

\section{Author(s) contributions}

I declare that I am the sole author of this research article.

\section{Ethical consideration}

This article followed all ethical standard for a research without direct contact with human or animal subjects.

\section{Funding information}

This research received no specific grant from any founding agency in the public, commercial, or not-for-profit sectors.

\section{Data availability statement}

Data sharing is not applicable to this article as no new data were created or analysed in this study.

\section{Disclaimer}

The views and opinions expressed in this article are those of the authors and do not necessarily reflect the official policy or position of any affiliated agency of the authors.

\section{References}

Balabanski, V., 2008, 'Mission in Matthew against the horizon of Matthew 24', New Testament Studies 54(2), 161-175. https://doi.org/10.1017/S002868850800009X

Barth, G., 1963, 'Matthew's understanding of the law', in G. Bornkamm, G. Bath \& H.J. Held (eds.), Tradition and interpretation in Matthew, pp. 58-164, SCM Press, London.

Beed, C. \& Beed, C., 2015, 'Governance egalitarianism in Jesus' teaching', Anglican Theological Review 97(4), 587-607.

Bornkamm, G., 1963, 'End-expectation and church in Matthew', in G. Bornkamm, G. Bath \& H.J. Held (eds.), Tradition and interpretation in Matthew, pp. 15-51, SCM Press, London.

Brown, R.E., 1983, 'Rome', in R.E. Brown \& J.P. Meier (eds.), Antioch and Rome: New Testament cradles of Catholic Christianity, pp. 87-216, Paulist Press, New York.

Brown, S., 1980, 'The Matthean Community and the Gentile Mission', Novum Testamentum 22(3), 193-221. https://doi.org/10.1163/156853680X00125

Carter, W., 2001, Matthew and Empire: Initial explorations, Trinity Press International, Harrisburg.

Carter, W., 2004, 'Matthew and gentiles: Individual conversion and/or systemic transformation?', Journal for the Studies of the New Testament 26(3), 259-282. https://doi.org/10.1177/0142064X0402600301

Clark, K.W., 1947, 'The gentiles bias in Matthew', Journal of Biblical Literature 66(2), 165-172. https://doi.org/10.2307/3262177

Davies, W.D. \& Allison, D.C., 2006a, A critical and exegetical commentary on the gospel according to Saint Matthew 1-7, The International Critical Commentary, vol. 1, T \& T Clark International, London.

Davies, W.D. \& Allison, D.C., 2006b, A critical and exegetical commentary on the gospel according to Saint Matthew 8-18, The International Critical Commentary, vol. 2, T \& T Clark International, London.

Davies, W.D. \& Allison, D.C., 2006c, A critical and exegetical commentary on the gospel according to Saint Matthew 19-28, The International Critical Commentary, vol. 3, T \& T Clark International, London.

Elliott, J.H., 2002, 'Jesus was not an egalitarian: a critique of an anachronist and idealist theory', Biblical Theology Bulletin 32(4), 75-91.

Evans, C.A., 2011, 'Fulfilling the law and seeking righteousness in Matthew and in the Dead Sea Scrolls', in D.M. Gurtner, J. Willitts \& R.A. Burridge (eds.), Jesus, Matthew's gospel and early Christianity: Studies in memory of Graham Stanton, pp. 102-114, T \& T Clark, London. 
Gundry, R., 1994, Matthew: A commentary on his handbook for a mixed Church under persecution, Eerdmans, Grand Rapids, MI.

Hare, D.R.A., 2000, 'How Jewish is the Gospel of Matthew?', Catholic Biblical Quarterly 62(2), 264-277.

Hare, D.R.A. \& Harrington, D.J., 1975, 'Make disciples of all the Gentiles (Mt 28:19)', Catholic Biblical Quarterly 37(3), 359-369.

Joubert, S.J., 1993, 'A bone of contention in recent scholarship: The "BIRKAT HAMINIM" and the separation of Church and Synagogue in the first century $A D^{\prime}$ Neotestamentica 27(2), 351-363.

Kampen, J., 1994, 'The sectarian form of the antitheses within the social world of the Matthean community', Dead Sea Discoveries 1(3), 338-363. https://doi. org/10.1163/156851794X00158

Kingsbury, J.D., 1991, 'Conclusion: Analysis of a conversation', in D.L. Balch (ed.), Social history of the Matthean community: Cross-disciplinary approaches, pp. 259-269, Fortress Press, Minneapolis, MN.

Luomanen, P., 1998, 'Corpus Mixtum-an appropriate description of Matthew's community?' Journal of Biblical Literature 117(3), 469-480.

Luz, U., 2001, Matthew 8-20: Hermeneia: A critical and historical commentary on the Bible, transl. J.E. Crouch, Fortress Press, Minneapolis, MN.

Luz, U., 2005, Matthew 21-28: Hermeneia: A critical and historical commentary on the Bible, transl. J.E. Crouch, Fortress Press, Minneapolis, MN.

Mclver, R.K., 1995, 'The parable of the weeds among the wheat (Mt 13:24-30, 36-43) and the relationship between the kingdom and the Church as portrayed in the Gospel of Matthew', Journal of Biblical Literature 114(4), 643-659. https://doi. org $/ 10.2307 / 3266479$

Meeks, W.A. \& Wilken, R.L., 1978, Jew and Christians in Antioch in the first four centuries of the common era, Scholars Press, Missoula, MT.

Meier, J.P., 1975, 'Salvation-history in Matthew: in search of starting point', Catholic Biblical Quarterly 37, 203-215.

Meier, J.P., 1976, Law and history in Matthew's Gospel: A redactional study of Mt. 5:17-48, Biblical Institute Press, Rome.

Olmstead, W.G., 2011, 'A gospel for a new nation: Once more, the ethnos of Matthew 21:43', in D.M. Gurtner, J. Willitts \& R.A. Burridge (eds.), Jesus, Matthew's Gospel and early Christianity: Studies in memory of Graham Stanton, pp. 115-132, T \& T Clark, London.

Overman, J.A., 1990, Matthew's Gospel and formative Judaism: The social world of the Matthean Community, Fortress, Minneapolis, MN.

Overman, J.A., 1996, Church and community in crisis: The Gospel according to Matthew, Trinity Press International, Valley Forge, PA.

Repschinski, B., 2006, “"For he will save his people from their sins" (Mt 1:21): A Christology for Christian Jews', Catholic Biblical Quarterly 68(2), 248-267.

Runesson, A., 2011, 'Judging gentiles in the Gospel of Matthew: Between "othering" and inclusion', in D.M. Gurtner, J. Willitts \& R.A. Burridge (eds.), Jesus, Matthew's Gospel and early Christianity: Studies in memory of Graham Stanton, pp. 133-151, T \& T Clark, London.
Saldarini, A.J., 1991, 'The Gospel of Matthew and Jewish-Christian conflict', in D.L. Balch (ed.), Social history of the Matthean community: Cross-disciplinary approaches, pp. 38-61, Fortress, Minneapolis, MN.

Saldarini, A.J., 1994, Matthew's Christian-Jewish community, The University of Chicago, Chicago, IL.

Schweizer, E., 1975, The good news according to Matthew, SPCK, London.

Senior, D.P., 2001, 'Directions in Matthean studies', in D.E. Aune (ed.), The Gospel of Matthew in the current study: Studies in memory of William $G$ Thompson, pp. 6-21, Eerdmans, Grand Rapids, MI.

Shin, I.C., 2004, 'Matthew's inclusive community: A narratological and social scientific reading', Unpublished PhD thesis, University of Pretoria.

Sim, D.C., 1998, The Gospel of Matthew and Christian Judaism: The history and social setting of the Matthean community, T \& T Clark, Edinburgh.

Sim, D.C., 2001, 'The social setting of the Matthean Community: New paths for an old Journey', HTS Teologiese Studies/Theological Studies 57(1\&2), 268-280. https:// doi.org/10.4102/hts.v57i1/2.1902

Sim, D.C., 2014, 'Is Matthew 28:16-20 the summary of the Gospel?', HTS Teologiese Studies/Theological Studies 70(1), 517-523. https://doi.org/10.4102/hts.v70i1.2756

Smith, R.H., 1992, 'Matthew's message for insiders: Charisma and commandment in a first-century community', Interpretation 46(3), 229-239. https://doi.org/10.1177/ 002096439204600302

Stanton, G.N., 1985, 'The origin and purpose of Matthew's Gospel: Matthean scholarship from 1945-1980', in H. Temporini \& W. Haase (eds.), Aufstieg und Niedergang der römischen Welt, vol. II 25.3, pp. 1889-1951, De Gruyter, Berlin.

Stanton, G.N., 1992, A gospel for a new people: Studies in Matthew, T \& T Clark, Edinburgh.

Stark, R., 1991, 'Antioch as the social situation for Matthew's Gospel', in D.L. Balch (ed.), Social history of the Matthean community: Cross-disciplinary approaches, pp. 87-111, Fortress, Minneapolis, MN

Stendahl, K., 1968, The school of St. Matthew, Fortress, Philadelphia, PA.

Thiesen, M., 2012, 'Abolishers of the Law in early Judaism and Matthew 5:17-20', Biblica 93(4), 543-556.

Trilling, W., 1964, Das wahre Israel: Studienzueinertheologie des Matthäusevangeliums, 3rd edn., Kösel, Munich.

Ulrich, D.W., 2007, 'The mission audience of the Gospel of Matthew', Catholic Biblical Quarterly 69(1), 64-83.

Van Aarde, A.G., 2005, 'Jesus' mission to all of Israel in Matthew's story', Neotestmentica 41(2), 416-436.

Van Aarde, A. G., 2007, 'Jesus' mission to all of Israel emplotted in Matthew's story', Neothestamentica 41(2), 416-436.

Van Veen, P., 2018, 'An alternative Pentateuchal view of Matthew', Calvin Theologica Journal 53(1), 65-98.

White, L.M., 1991, 'Crisis management and boundary maintenance: The social location of the Matthean community', in D.L. Balch (ed.), Social history of the Matthean community: Cross-disciplinary approaches, pp. 211-247, Fortress, Minneapolis, MN. 